\title{
Surface- and deep-water hydrography and meltwater events in the mid-latitude North Atlantic Ocean over the past 160,000 years
}

\author{
Myong-Ho Park ${ }^{1}$, Thorsten Kiefer ${ }^{2}$, and Rainer Zahn ${ }^{3}$ \\ ${ }^{\prime}$ Department of Earth System Sciences, Yonsei University, Shinchon-dong 134, \\ Seodaemun-gu, Seoul 120-749, South Korea <mpark0213@hanmail.net> \\ ${ }^{2}$ Institut für Geowissenschaften der Universität, Olshausenstrasse 149, D-24098 Kiel, \\ Germany \\ ${ }^{3}$ Department of Earth Sciences, University of Wales, P.O. Box 914, Cardiff CF10 3YE, \\ United Kingdom
}

Date Received: August 15, 2001

Date Accepted: January 18, 2002

\begin{abstract}
An investigation involving stable oxygen and carbon isotopes on core M15612 from the Mid-Atlantic Ridge (44 ${ }^{\circ} \mathrm{N}$, $26^{\circ} \mathrm{W}$ ) shows that distinct negative $\delta^{18} \mathrm{O}$ anomalies punctuate the planktonic isotope records and correlate with the ice-rafted detritus (IRD) events. Within most IRD layers, detrital carbonate contributes between 1 and $13 \%$ and supports the contention that the layers are the southern equivalents of the northern North Atlantic Ocean's Heinrich events. Anomalies are strongest for the Neogloboquadrina pachyderma (sinistral coiling) isotope record. Systematic changes in the $\delta^{18} \mathrm{O}$ offset between Globigerina bulloides and Globorotalia inflata signify variations in the mid-latitude thermocline structure. In conjunction with negative benthic $\delta^{13} \mathrm{C}$ anomalies, the data document a stronger contribution of an ${ }^{18} \mathrm{O}$-depleted, nutrientrich water mass during the Heinrich events. The $\delta^{13} \mathrm{C}$ amplitude of $>1 \%$ between 25 and $57 \mathrm{ka}$ indicates changes between northern-source (North Atlantic Deep Water) and southern-source (Antarctic Bottom Water.) water masses at this site. The Heinrich layers in the mid-latitude core are correlative with those from a core off Portugal. This synchronicity may have resulted from common changes in a North Atlantic thermohaline switch.
\end{abstract}

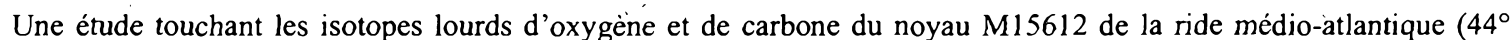
nord, $26^{\circ}$ ouest) révèle que des anomalies négatives distinctes de $\delta^{18} \mathrm{O}$ ponctuent les enregistrements d'isotopes planctoniques et les rapprochent avec des phénomènes d'alimentation en débris glaciels. La contribution du carbonate détritique varie entre 1 et $13 \%$ à l'intérieur de la majorité des couches de débris glaciels', ce qui conforte la théorie que les couches constituent les équivalents méridionaux des phénomènes de Heinrich septentrionaux de l'Atlantique Nord. Les anomalies sont les plus prononcées dans le cas de l'enregistrement d'isotopes de Neogloboquadrina pachyderma (enroulement sénestre). Les changements systématiques dans le décalage de $\delta^{18} \mathrm{O}$ entre le Globigerina bulloides et le Globorotalia inflata témoignent de variations dans la structure de la thermocline de latitude moyenne. Conjointement à des anomalies de $\delta^{13} \mathrm{C}$ benthiques négatives, les données documentent une contribution plus marquée d'une masse d'eau riche en éléments nutritifs et à faible teneur en ${ }^{18} \mathrm{O}$ pendant les phénomènes de Heinrich. L'amplitude de $\delta^{13} \mathrm{C}$ de $>1 \%$ entre 25 et $57 \mathrm{Ka}$ révèlent des changements entre les masses d'eau d'origine septentrionale (eaux profondes de l'Atlantique Nord) et d'origine méridionale (eaux de fond de l'Antartique) en cet emplacement. L̀es couches de Heinrich du noyau de latitude moyenne se rapprochent de celles d'un noyau au large du Portugal. Cette synchronicité pourrait découler de changements communs dans une substitution thermohaline de l'Atlantique Nord.

Traduit par la rédaction

\section{INTRODUCTION}

A series of distinct IRD layers in the North Atlantic Ocean punctuates glacial and deep-sea sediments (Heinrich 1988; Broecker et al. 1992). The IRD layers, commonly named "Heinrich" layers, have a mineral assemblage containing often more than $20 \%$ detrital carbonate material. The Heinrich layers are found mostly between $45^{\circ}$ and $55^{\circ} \mathrm{N}$ latitude (Bond et al. 1992). The detrital carbonate fragments in the Heinrich layers decrease in abundance eastwards, pointing to the Laurentide ice sheet as the most likely source, the ice shedding fragments by way of massive iceberg discharges (Broecker et al. 1992). At times, such icebergs and their discharge reached as far as the Portuguese margin (e.g. Bond et al. 1992; Grousset et al. 2000).

It seems that during the last glacial period, thermohaline circulation was broken repeatedly by massive melting of icebergs (Maslin et al. 1995). This may have been because the production of North Atlantic Deep Water (NADW) ceased, or because the region of sinking changed (Sarnthein et al. 1994). On the basis of depleted benthic $\delta^{13} \mathrm{C}$ and estimates of decreased sea-surface temperature from faunal assemblages (Maslin et al. 1995), the glacial circulation of the North Atlantic underwent convection breakdown during the Heinrich events. 
Some authors (e.g. Lebreiro et al. 1996; Zahn et al. 1997; Baas et al. 1998; Grousset et al. 2000; Thomson et al: 2000) have extended the study of Heinrich layers to the eastern North Atlantic and the far eastern boundary of the presumed iceberg flow. These studies demonstrate that cores from the eastern sector of the North Atlantic contain signals consistent with the Heinrich events, but strongly attenuated.

In this study, we present paleo-oceanographic data from high-resolution measurements of cores from the Mid-Atlantic Ridge, northern North Atlantic and Portuguese margin. Particularly, core M15612 was used to monitor surface- and deep-water properties in association with North Atlantic meltwater events over the past 160,000 years. Our profiles make possible the monitoring of even small changes in surface and deep hydrography on glacial-interglacial to millennial time scales. Finally, the Heinrich events in the cores are correlated and discussed.

\section{MATERIALS AND METHODS}

Core M15612 was collected from the Mid-Atlantic Ridge north of the Azores (Fig. 1; Table 1). The site of core M15612 is thus close to the glacial polar front, and its depth position is at the hydrographic front between glacial deep and bottom water masses (Ruddiman 1977). Core SO75-26KL, from the southern Portuguese margin at $37^{\circ} 49^{\prime} \mathrm{N}$, and DSDP site 609 , at $49^{\circ} 53^{\prime} \mathrm{N}$, were used to correlate fluctuations of the IRD events with those of core M15612.

For coarse fraction analysis, core M15612 was continuously sampled at $5 \mathrm{~cm}$ intervals, and additional samples were taken at $1.5 \mathrm{~cm}$ intervals in the Heinrich layers in order to obtain a higher stratigraphic resolution. Coarse sediment grains $(>63 \mu \mathrm{m})$ were counted to determine the ratios of biogenic and terrigenous components. An estimate of the relative abundance of planktonic foraminifera $(>125 \mu \mathrm{m})$ was also made.

Stable oxygen/carbon isotope analyses were performed on several foraminifera species: about 25 specimens of each of the planktonic foraminifera species Globigerina bulloides, Globorotalia inflata and Neogloboquadrina pachyderma and 2 to 6 specimens of each of the benthic foraminifera species Cibicidoides wuellerstorf $i$ and Cibicidoides kullenbergi. Prior to isotope analyses, the tests were cracked open and ultrasonically cleaned in reagent-grade methanol, dried at $40^{\circ} \mathrm{C}$, and transferred to the KIEL CARBOPREP device. The samples were placed in orthophosphoric acid at $90^{\circ} \mathrm{C}$ in an on-

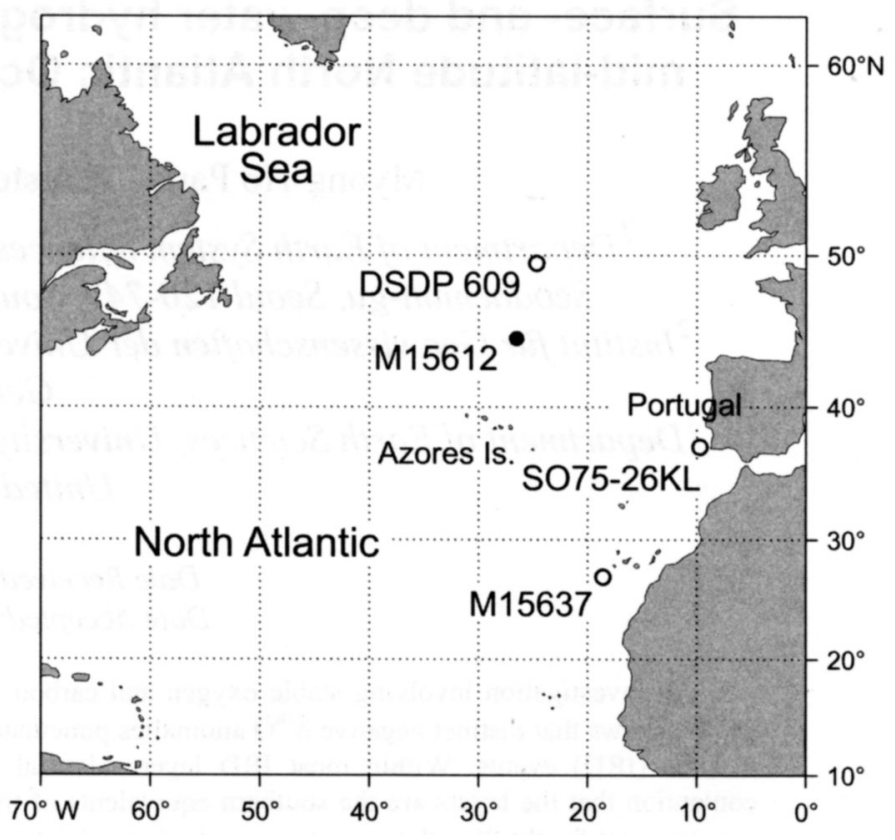

Fig. 1. Core locations in the North Atlantic Ocean. The closed circle indicates the study core, and open circles indicate the cores referenced in the literature that are used in this study for comparison. See also Table 1 .

line automated carbonate preparation device. The evolved $\mathrm{CO}_{2}$ was analyzed using the mass spectrometer FINNIGAN MAT 251 in Kiel, Germany. The long-term reproducibility was $0.07 \%$ for $\delta^{18} \mathrm{O}$ and $0.04 \%$ for $\delta^{13} \mathrm{C}$ as calculated from replicate analyses of internal carbonate standards. All isotope data are expressed in the standard $\delta$ notation, which is in \%o relative to the PDB scale.

The ${ }^{14} \mathrm{C}$ ages of core $\mathrm{M} 15612$ were compiled from the data of Kiefer (1998), which were measured by AMS using the 3MV Tandetron system at the Leibniz Laboratory, University of Kiel (Nadeau et al. 1997). Monospecific samples of $G$. inflata and $N$. pachyderma containing 300 to 1200 tests in the size fractions $315-400 \mu \mathrm{m}$ (for $G$. inflata) and 250-315 $\mu \mathrm{m}$ (for $N$. pachyderma) were used (Table 2). In order to minimize the bias of bioturbational mixing, samples were picked at relative maxima of the species dated.

Stratigraphic control of core M15612 was mainly based on AMS ${ }^{14} \mathrm{C}$ ages (Table 2) and foraminiferal oxygen isotope stratigraphy (Martinson et al. 1987). The initial age model was based on the benthic $\delta^{18} \mathrm{O}$ decrease at the end of Younger

Table 1. Location of the cores used in this study

\begin{tabular}{cccccl}
\hline Core No. & $\begin{array}{c}\text { Latitude } \\
(\mathrm{N})\end{array}$ & $\begin{array}{c}\text { Longitude } \\
(\mathrm{W})\end{array}$ & $\begin{array}{c}\text { Water depth } \\
(\mathrm{m})\end{array}$ & $\begin{array}{c}\text { Local bottom } \\
\text { water mass }\end{array}$ & Source \\
\hline M15612 & $44^{\circ} 21^{\prime} 36^{\prime \prime}$ & $26^{\circ} 32^{\prime} 36^{\prime \prime}$ & 3050 & NADW & This study \\
M15637 & $28^{\circ} 53^{\prime} 00^{\prime \prime}$ & $1^{\circ} 14^{\prime} 00^{\prime \prime}$ & 1884 & NADW & Zahn (1986), Kiefer (1998) \\
SO75-26KL & $37^{\circ} 49^{\prime} 18^{\prime \prime}$ & $9^{\circ} 19^{\prime} 54^{\prime \prime}$ & 1099 & NADW/MOW & Park (1994), Zahn et al.$(1997)$ \\
DSDP 609 & $49^{\circ} 53^{\prime} 00^{\prime \prime}$ & $24^{\circ} 14^{\prime} 00^{\prime \prime}$ & 3884 & NADW & Bond et al. (1992, 1993) \\
\hline
\end{tabular}

\footnotetext{
${ }^{1} \mathrm{NADW}=$ North Atlantic Deep Water, MOW $=$ Mediterranean Outflow Water
} 
Table 2. ${ }^{14} \mathrm{C}$-AMS ages for core M15612

\begin{tabular}{rrcrcrll}
\hline $\begin{array}{c}\text { Depth } \\
\text { interval }^{1}\end{array}$ & $\begin{array}{c}\text { Mean } \\
\text { depth }^{1}\end{array}$ & Species & $\begin{array}{c}\# \\
\text { analyzed }\end{array}$ & $\begin{array}{c}{ }^{14} \mathrm{C} \text { age } \\
(\mathrm{yr})\end{array}$ & $\begin{array}{c}\text { Error } \\
+/-\end{array}$ & $\begin{array}{l}\text { Calendar } \\
\text { age (ka) }\end{array}$ & $\begin{array}{l}\text { References for } \\
\text { calendar age }\end{array}$ \\
\hline $0-1.5$ & 0.75 & G. inflata & 500 & 2,229 & 3131 & 2.23 & Stuiver and Pearson (1993) \\
$8.0-9.0$ & 8.50 & G. inflata & 500 & 4,074 & 2828 & 4.53 & Stuiver and Pearson (1993) \\
$33.0-34.5$ & 34.75 & G. inflata & 500 & 12,091 & 5656 & 14.32 & linear interp. \\
$44.0-45.5$ & 44.75 & N. pachyderma & 1200 & 14,955 & 6362 & 15.97 & linear interp. \\
$52.0-53.0$ & 52.50 & N. pachyderma & 1000 & 16,465 & 108107 & 17.90 & linear interp. \\
$68.0-69.0$ & 68.50 & N. pachyderma & 650 & 19,050 & 110110 & 22.08 & linear interp. \\
$72.0-73.0$ & 72.50 & N. pachyderma & 900 & 18,394 & 107106 & 23.13 & linear interp. \\
$74.0-75.0$ & 74.50 & N. pachyderma & 750 & 20,520 & 180180 & 23.65 & H2 top (GISP2) \\
$81.5-83.0$ & 82.25 & N. pachyderma & 850 & 21,255 & 108106 & 24.58 & linear interp. \\
$86.0-87.5$ & 86.75 & N. pachyderma & 1000 & 22,180 & 102101 & 25.62 & linear interp. \\
$98.0-99.0$ & 98.50 & G. inflata & 380 & 23,938 & 139137 & 28.33 & linear interp. \\
$106.5-107.5$ & 107.00 & N. pachyderma & 1200 & 26,638 & 287277 & 30.18 & H3 base (GISP2) \\
$133.5-135.0$ & 134.25 & G. inflata & 300 & 32,027 & 273264 & 37.11 & linear interp. \\
$150.0-151.0$ & 150.50 & N. pachyderma & 1000 & 34,814 & 503473 & 39.92 & linear interp. \\
\hline
\end{tabular}

${ }^{1}$ Depth intervals and mean depth in $\mathrm{cm}$.

Dryas cold event (11.6 cal. ka; Meese et al. 1994) and at the onset of stage 4 maximum (71.1 cal. ka). Holocene age control points were established from ${ }^{14} \mathrm{C}$ dates and then converted to calendar ages (Stuiver et al. 1998).

\section{RESULTS}

\section{Stratigraphy}

The upper IRD records of core M15612 show 6 distinct IRD maxima, which reveal clearly Heinrich layers 1 (H1) to 6 (H6), although two peaks ( $\mathrm{H} 3$ and $\mathrm{H} 6)$ are of relatively low magnitude (Fig. 2). An additional age control point was obtained by assigning the IRD records in core M15612 to the well-documented ages of the corresponding oxygen-isotope minima in the GISP ice core. In this way, ${ }^{14} \mathrm{C}$ ages of the Heinrich events were obtained and $\mathrm{H} 1, \mathrm{H} 2, \mathrm{H} 3$ and $\mathrm{H} 4$ were dated at 12.3-15.0, 20.0-21.3, 26.6 and 33.8-35.4 ka, respectively.

According to the age models, the stable isotope records of the core cover the time interval from the penultimate fullglacial stage 6 to the Holocene. The glacial-interglacial transitions of Terminations I and II are documented by $\delta^{18} \mathrm{O}$ shifts of up to $2 \%$ in:the planktonic and benthic records (Fig. 2a). The largest isotope shifts are documented in the $\delta^{18} \mathrm{O}$ record obtained from $G$. bulloides, which is a near-surface dweller, and thus records a strong temperature signal. $G$. inflata, on the other hand, lives at greater water depths and records attenuated temperature signals (Fig. 3a). Systematic changes in the $\delta^{18} \mathrm{O}$ offset between these planktonic species signify changes in the mid-latitude thermocline structure. Negative excursions of the planktonic and benthic $\delta^{18} \mathrm{O}$ records occur together with significant increases in abundance of $N$. pachyderma, pointing to the influence of meltwater or subpolar water of the site of core M15612.

Following on from the above results, we calculate that, over the past 160,000 years, mean sedimentation rate was 3.05 $\mathrm{cm} / \mathrm{kyr}$ (Fig. 2). This rate is very low compared with those at the upper continental slope off Portugal $(15.9 \mathrm{~cm} / \mathrm{kyr}$ for core SO75-26KL): sedimentation rates at the continental shelf and slope are one order of magnitude higher than those computed for Mid-Atlantic core M15612 and the North Atlantic cores (e.g. $2.5 \mathrm{~cm} / \mathrm{kyr}$ for core M15637; Kiefer 1998). The low sedimentation rate of core M15612 is surely due to pelagic accumulation rates in open ocean plains. However, sedimentation rates increase dramatically to $18 \mathrm{~cm} / \mathrm{kyr}$ during $\mathrm{H} 1$ and $12 \mathrm{~cm} / \mathrm{kyr}$ during $\mathrm{H} 2$, respectively, reflecting twofold to sixfold increase in sediment flux during Heinrich events (Fig. 2c).

\section{Composition of coarse fraction}

Core M15612 contains predominantly pelagic foraminiferal ooze with minor contributions from pteropod shells. This uniform sediment distribution is interrupted only in the upper section, between 10 and $40 \mathrm{ka}$, and near the base of the core, where the Heinrich layers occur (Fig. 3c). Detrital carbonate contributes $1-13 \%$ of the detrital fraction of the Heinrich layers. $\mathrm{H} 1$ and $\mathrm{H} 2$ consist of over $90 \%$ terrigenous material, of which detrital carbonate comprises up to $10 \%$. Within the Heinrich layers, the terrigenous fraction accounts for $25 \%(\mathrm{H} 6)$ to nearly $100 \%(\mathrm{H} 2)$. $\mathrm{H} 3$ and $\mathrm{H} 6$ are more pronounced in the $>63 \mu \mathrm{m}$ fraction than in the $>125 \mu \mathrm{m}$ fraction (Fig. 3c). The largest part of the Heinrich layers consist of transparent angular quartz grains, angular to subangular feldspar and dolomite particles. The IRD layers in the deeper section between 125 and $150 \mathrm{~cm}$ are composed of 20 to $45 \%$ IRD fractions, but these do not contain any detrital carbonates (see below). 
a)

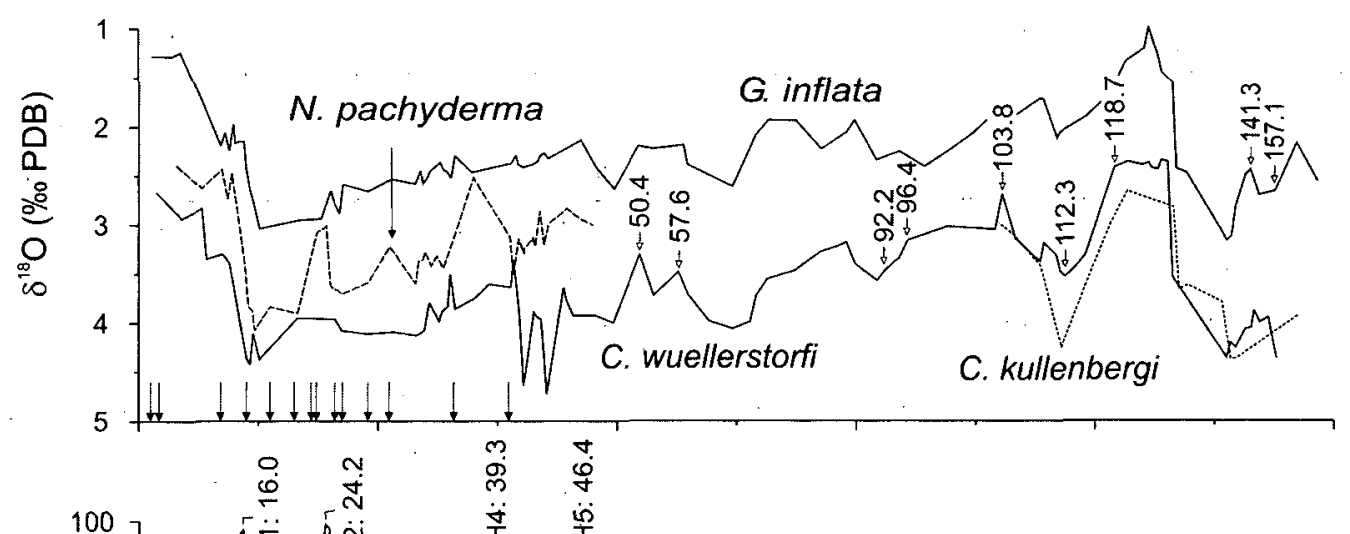

b)

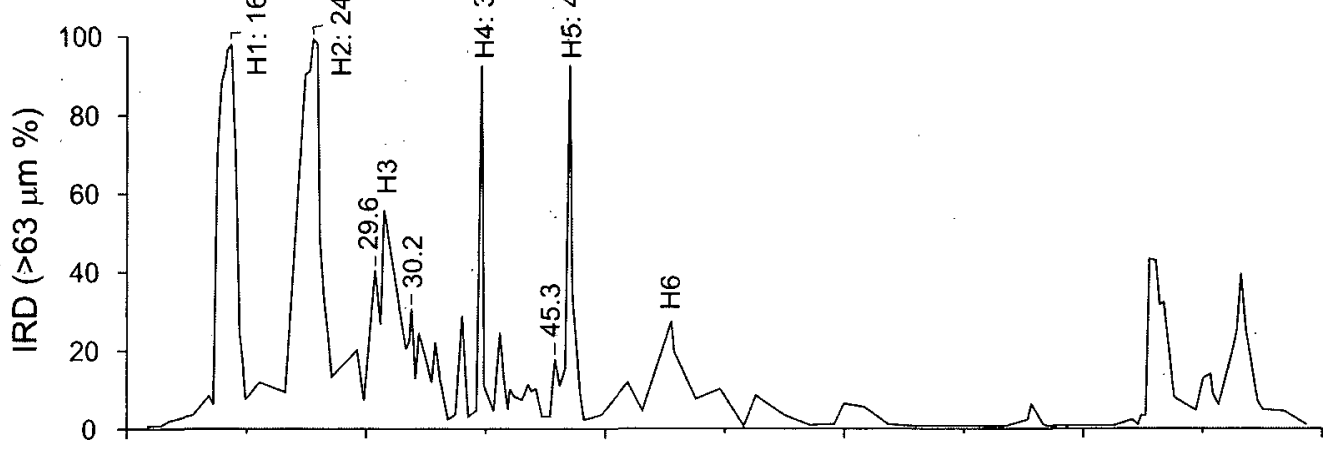

c)

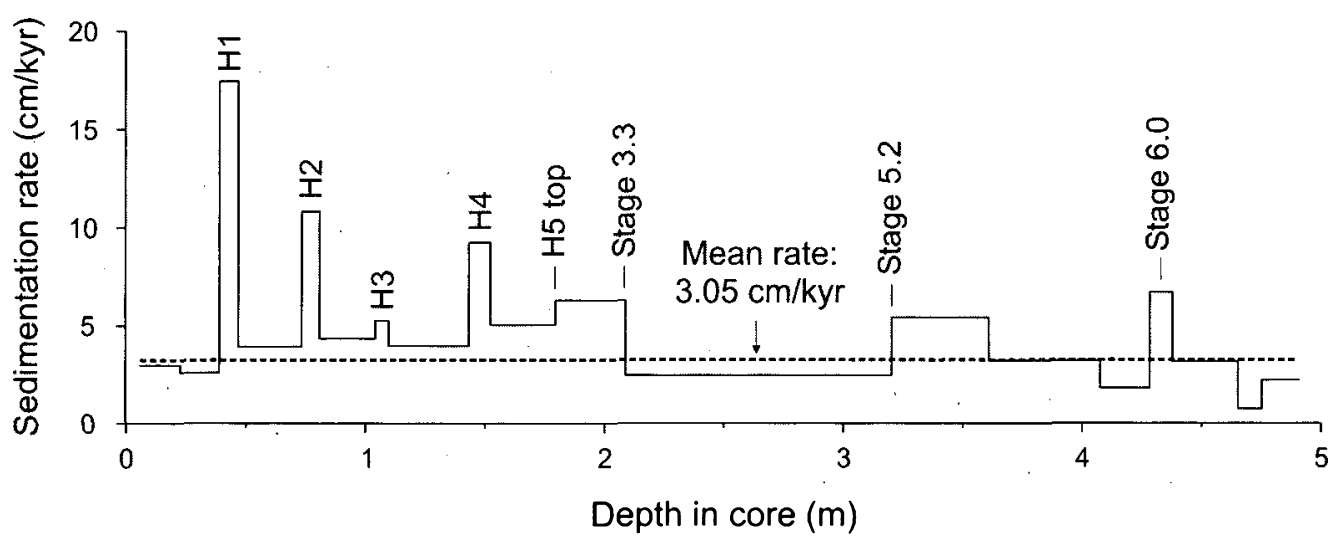

Fig. 2. Age model developed for the late Quaternary section of core M15612: a) $\delta^{18} \mathrm{O}$ records measured on foraminiferal tests of Globorotalia inflata, Neogloboquadrina pachyderma, Cibicidoides wuellerstorfi and Cibicidoides kullenbergi. Number on the open arrow indicates the fixpoint in $\delta^{18} \mathrm{O}$ stratigraphy with unit of calendar ka B.P., and black arrow represents the core depth obtained by AMS ${ }^{14} \mathrm{C}$-dating (see Table 2 ). b) Percentage of IRD in the $>63 \mu \mathrm{m}$ fraction. Small bar without arrow marks the fix-point taken from the data of GISP2. c) Sedimentation rate of core M15612.

Faunal analyses of core M15612 show that the Heinrich layers are associated with a distinct pattern of foraminiferal abundances (Fig. 3b). N. pachyderma tends to abundance maxima in or near the Heinrich layers. In the same intervals, the rest of the planktonic foraminiferal community almost disappears, further supporting the existence of an exotic polar or subpolar environment that could be tolerated only by $N$. pachyderma.

\section{$\delta^{13} \mathrm{C}$ anomalies in core $\mathrm{M} 15612$}

During the past 70,000 years, $\delta^{13} \mathrm{C}$ records from core M15612 show clear response to the Heinrich events and variations in sea-surface temperature (Fig. $4 a, b$ ). Therefore, these $\delta^{13} \mathrm{C}$ values primarily monitor variability of surface- and deep-water masses, although they also trace the intensity of ventilations in the North Atlantic.

Planktonic ( $G$. bulloides) $\delta^{13} \mathrm{C}$ is depleted up to $1 \%$ compared to benthic (C. wuellerstorfi) $\delta^{13} \mathrm{C}$, but the benthic $\delta^{13} \mathrm{C}$ values commonly decrease $0.2-0.5 \%$ during the Heinrich events. The close correlation of minimum $\delta^{13} \mathrm{C}$ values and maximum IRD abundances in core M15612 suggests that thermohaline convection in the subpolar North Atlantic was reduced during massive iceberg discharge and meltwater flow. A similar pattern was also observed on the Portuguese margin (Zahn et al. 1997). However, superimposed on the benthic $\delta^{13} \mathrm{C}$ patterns is a long-term trend with positive $\delta^{13} \mathrm{C}$ values around $1-1.5 \%$ between 25 and $57 \mathrm{ka}$. The $\delta^{13} \mathrm{C}$ amplitude of more than $1 \%$ in this time interval indicates changes between northern-source (North Atlantic Deep Water) and southernsource (Antarctic Bottom Water) water masses at this site. 
a)

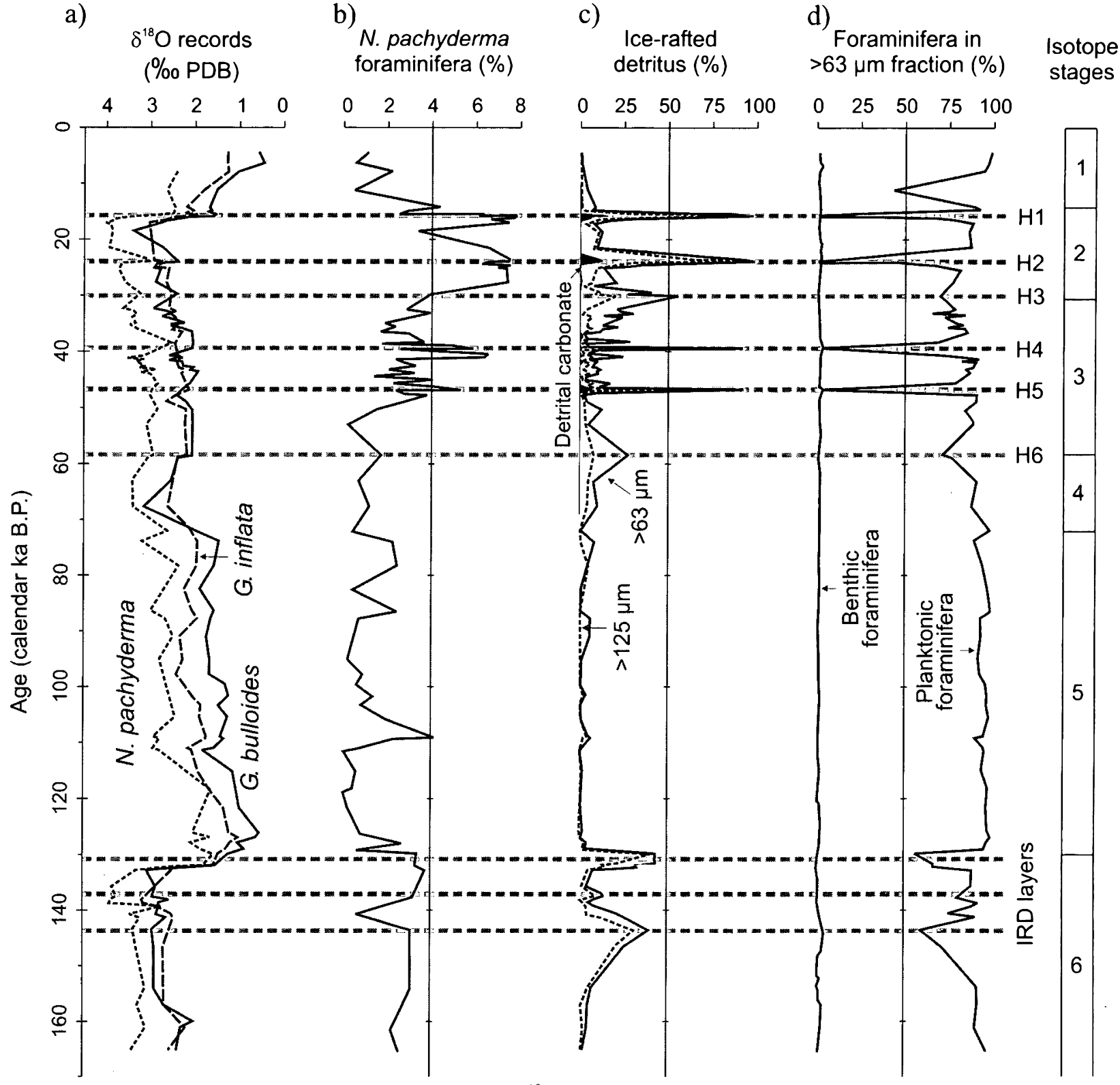

Fig. 3. a) Correlation of the Heinrich events with the planktonic $\delta^{18} \mathrm{O}$ records. b) Abundance pattern of Neogloboquadrina pachyderma as a percent of total planktonic foraminifera. c) Distribution of the IRD layers. d) Abundance of the planktonic and benthic foraminiferal grains in the $>63 \mu \mathrm{m}$ fraction.

\section{DiscuSSION}

\section{Correlation between IRD layers at Mid-Atlantic core M15612 and DSDP 609}

As mentioned above, all IRD layers from core M15612 are characterized by the maximum abundance of lithic fragments, abundance maximum of $N$. pachyderma and relative high percentages of dolomite except for $\mathrm{H} 3$ and $\mathrm{H} 6$, in which the IRD layers are detrital carbonate free. Examination using optical microscopy did not reveal any detrital calcite in the IRD layers of the core. It is generally thought that, through progressive melting of the icebergs, detrital calcite-rich carbonates would be released and would partly dissolve in the water column. The fact that IRD layers in core M15612 contain little or no detrital calcite could be explained by the possibility that ice-rafted detrital calcite is more susceptible to dissolution than dolomite.

Compared to DSDP 609, the Heinrich layers in core M15612 contain only small amounts of dolomite in the detrital carbonate fraction. The two IRD layers in the lower part of the core (between 125 and $144 \mathrm{ka}$ ) show no indication of the presence of detrital carbonates at all. The IRD layers in the DSDP 609 indicate that $\mathrm{H1}, \mathrm{H} 2, \mathrm{H} 4$ and $\mathrm{H} 5$ contain layers with $20-25 \%$ detrital carbonates, whereas carbonate is absent in $\mathrm{H} 3$ and $\mathrm{H} 6$, as shown in core M15612 (Fig. 5).

Similar to the signals observed at DSDP 609, Heinrich events $\mathrm{H} 1$ to $\mathrm{H} 6$ in core M15612 coincide with distinct minima of the planktonic foraminiferal fauna and maximum abundances of the left-coiling form of $N$. pachyderma (Fig. 3). However, negative anomalies of the $N$. pachyderma $\delta^{18} \mathrm{O}$ values in the core 


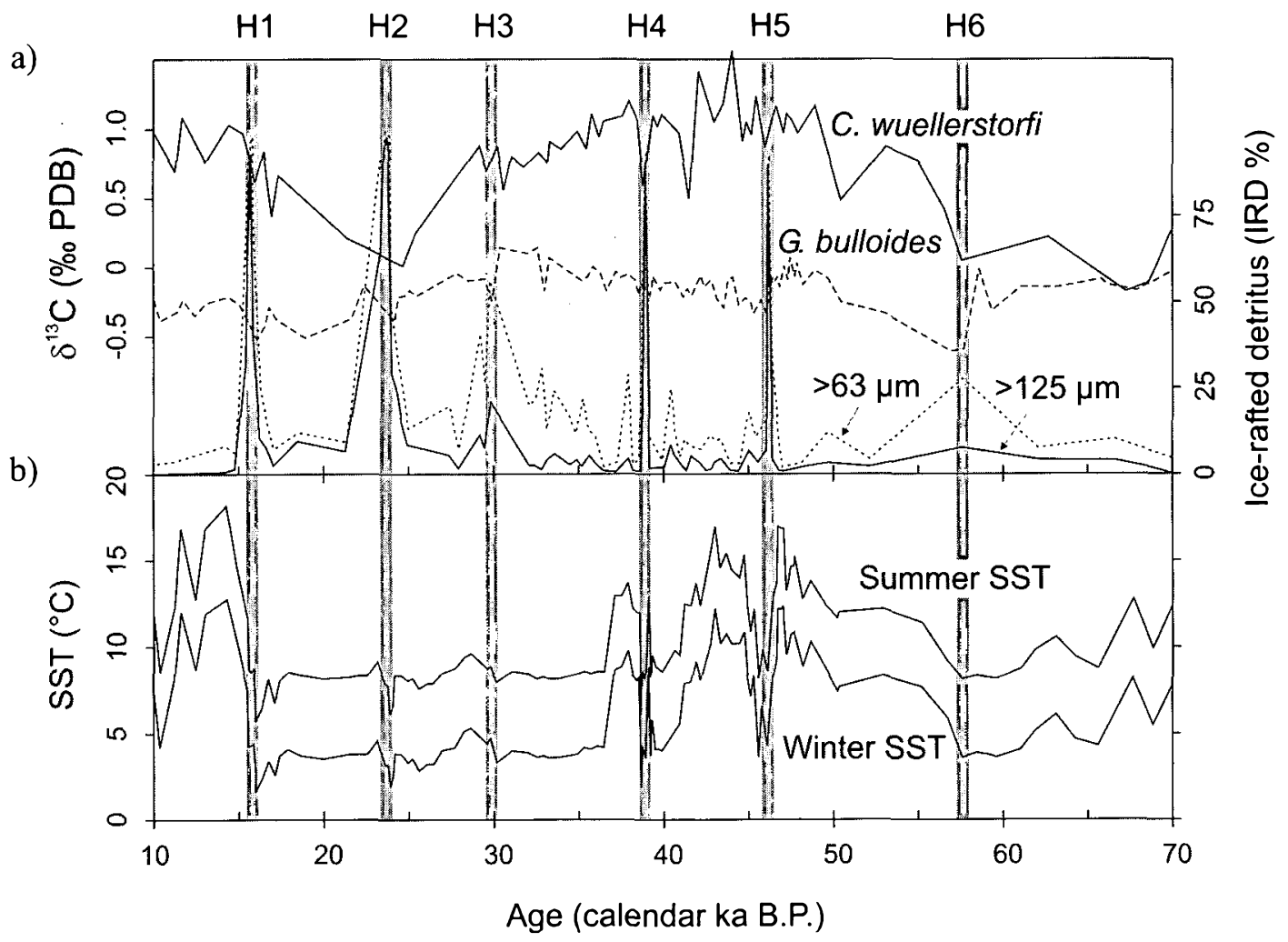

Fig. 4. Correlation of the data between 10-70 ka in core M15612: a) Foraminiferal $\delta^{13} \mathrm{C}$ records and IRD patterns in the $>63 \mu \mathrm{m}$ and $>125 \mu \mathrm{m}$ fractions. b) SST for summer and winter estimated from planktonic foraminiferal assemblage (SIMMAX; for details see Kiefer (1998)).
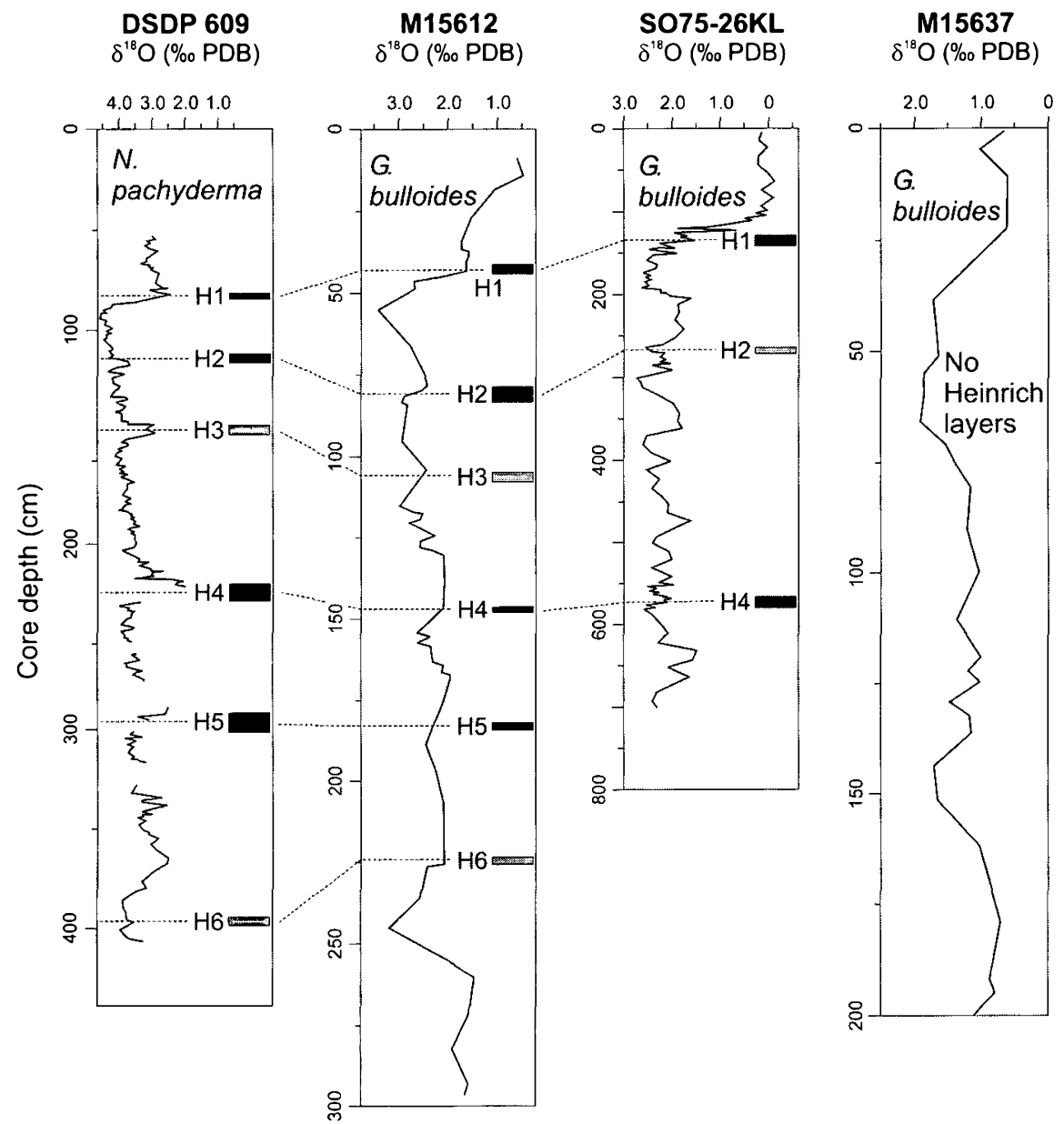

Fig. 5. Occurrence of the Heinrich events (horizontal bars) in cores used in this study. Solid bars indicate IRD events with detrital carbonates, shaded bars indicate IRD layers with no detrital carbonates. 
are recorded from $\mathrm{H} 1$ to $\mathrm{H} 4$. For $\mathrm{H} 5$ and $\mathrm{H} 6$, these values show only weak response to the IRD event. Surprisingly, $N$. pachyderma shows the same $\delta^{18} \mathrm{O}$ response as recorded by $G$. bulloides and $G$. inflata. The observation that $G$. bulloides and $G$. inflata show different isotope signals from that of $N$. pachyderma may be the result of ecological factors: that is, $N$. pachyderma prefers a polar environment similar to that existing during the Heinrich events, whereas G. bulloides and G. inflata are boreal species and presumably could not tolerate polar environments. Therefore, the last two species decreased sufficiently in abundance (or vanished completely) to be no longer reliable recorders of surface-subsurface water conditions. If this were indeed the case, the $\delta^{18} \mathrm{O}$ values of both species during the Heinrich events would be strongly disturbed by bioturbation, which mixes in shells from pre- and post-IRD event sections, in which the two species are abundant.

Subtle differences between the IRD records of core M15612 and DSDP 609 may be ascribed to the fact that core M15612 is located close to the southern limit of maximum iceberg flow, whereas DSDP 609 is located in the maximum flow path of icebergs. Also, the magnitude of the various IRD events in core M15612 would depend on the position of the axis of the iceberg flow path and this, in turn, may be a function of climate and magnitude of iceberg shedding.

\section{Correlation between IRD layers from the open North Atlantic and Upper continental margin off Europe and Africa}

The records of core SO75-26KL from the upper Portuguese continental margin document the existence of distinct IRD layers during MIS (Marine-oxygen Isotope Stage) 2/3 (Zahn et al. 1997; Schönfeld and Zahn 2000). On the other hand, core M15637 does not contain any Heinrich-IRD layers (Figs. 1, 5). The IRD layers in core SO75-26KL contain less detrital minerals than those observed at the Mid-Atlantic core M15612. The mineral assemblage of some IRD layers in the core is very similar to that of the Heinrich layers in core M15612. For example, the dolomite contained in $\mathrm{H} 1$ and $\mathrm{H} 4$ in core SO75$26 \mathrm{KL}$ suggests that both layers are correlative with the open North Atlantic events. In contrast, H2 in core SO75-26KL does not contain detrital carbonate (Fig. 5). This is in contrast to the findings from the open North Atlantic, where H2 contains significant amounts of dolomite; enhanced dolomite content is also documented for $\mathrm{H} 2$ in core M15612 (Fig. 3). In fact, the broader dolomite maximum observed for $\mathrm{H} 2$ in core $\mathrm{M} 15612$ implies a stronger input of dolomite compared to the other peaks in the same core. Yet, dolomite is missing from what is inferred here to be the Portuguese-margin equivalent of $\mathrm{H} 2$. Thus, iceberg flow during this full-glacial event may not have been as severe as the one recorded for Termination I, so that only a few icebergs would have reached the Portuguese margin, and at this distance they would have lost most of their original paleooceanographic signals.

The close correlation between the benthic $\delta^{13} \mathrm{C}$ decreases and occurrences of Heinrich events from the eastern North Atlantic are suggestive of mid-depth circulation changes that were related to changing surface ocean conditions (Zahn et al. 1997). Also, $\delta^{13} \mathrm{C}$ records from the study area support the possibility of a linkage between sea-surface conditions and thermohaline overturns in the North Atlantic. A similar pattern of stable isotope data from both the area north of the Azores and an area of the eastern North Atlantic off Portugal suggests common paleoclimatic changes during the most recent glacialinterglacial climate cycles, indicating large-scale forcing elements in the climate system.

\section{Conclusions}

Coarse-fraction counting shows that IRD layers exist in the upper section of core M15612, which are clearly associated with $\mathrm{H} 1$ to $\mathrm{H} 6$ observed at open North Atlantic sites. These layers show paleo-oceanographic features which are identical to Heinrich layers. These include maximum abundance of planktonic foraminifera $N$. pachyderma and occurrence of detrital carbonates. Except for H3, H6 and IRD layers during Termination II, the dolomite accounts for between $1-13 \%$ of terrigenous material.

Salinity excursions, as suggested by distinctly negative $\delta^{18} \mathrm{O}$ anomalies, are documented in all IRD layers. According to the results from $\delta^{13} \mathrm{C}$ analysis, benthic $\delta^{13} \mathrm{C}$ values decrease during the Heinrich events, documenting reduced ventilation in the North Atlantic. In contrast, benthic $\delta^{13} \mathrm{C}$ values increase $1-1.5 \%$ between 25 and $57 \mathrm{ka}$, implying hydrographic changes between northern-source (NADW) and southern-source (AABW) water masses at this site.

The Heinrich layers in core M15612 are correlative with the IRD layers from core SO75-26KL and DSDP 609. These layers from the Portuguese margin correlate with $\mathrm{H} 1, \mathrm{H} 2$ and $\mathrm{H} 4$ from core M15612 and DSDP 609. This synchronicity may have been derived from common changes in a North Atlantic thermohaline switch.

\section{ACKNOWLEDGMENTS}

The authors thank Hermann R. Kudrass for providing the samples of SO75-core and Joachim Schönfeld for his useful comments on the Quaternary foraminiferal ecology. Special thanks are due to editor Robert A. Fensome, and to John Shaw and an unnamed reviewer for their constructive reviews.

\section{REFERENCES}

BAAS, J.H., SCHÖNFELD, J., \& ZAHN, R. 1998. Mid-depth oxygen drawdown during Heinrich events: evidence from benthic foraminiferal community structure, trace fossil tiering and benthic $\delta^{13} \mathrm{C}$ at the Portuguese margin. Marine Geology, 152, pp. $25-55$.

Bond, G., Heinrich, H., Broecker, W., Labeyrie, L., McManus, J., Andrews, J., Huon, S., Jantschik, R., Clasen, S., Simet, C., Tedesco, K., Klas, M., Bonani, G., \& IVy, S. 1992. Evidence for massive discharges of icebergs into the North Atlantic Ocean during the last glacial period. Nature, 360, pp. 245-249.

Bond, G., Broecker, W., Johnsen, S., McManus, J., Labeyrie, L., JOUZEL, J., \& BONANI, G. 1993. Correlations between climate records from North Atlantic sediments and Greenland ice. Nature, 365, pp. 143-147.

Broecker, W.S., Bond, G., Klas, M., Clark, E., \& McManus, J. 
1992. Origin of the northern Atlantic's Heinrich events. Climate Dynamics, 6, pp. 265-273.

Grousset, F.E., Pujol, C., Labeyrie, L., Auffret, G., \& Boelaert, A. 2000. Were the North Atlantic Heinrich events triggered by the behavior of the European ice sheets? Geology, 28, pp. 123126.

HEINRICH, H. 1988. Origin and consequences of cyclic ice rafting in the northeast Atlantic Ocean during the past 130,000 years. Quaternary Research, 29, pp. 142-152.

KIEFER, T. 1998. Produktivität und Temperaturen im subtropischen Nordatlantik: zyklische und abrupte Veränderungen im späten Quartär. Reports, Institute of Geosciences, University of Kiel, no. 90,127 p.

Lebreiro, S.M., Moreno, J.C., McCave, I.N., \& Weaver, P.P.E. 1996. Evidence for Heinrich layers off Portugal (Torre Seamount: $39^{\circ} \mathrm{N}, 12^{\circ} \mathrm{W}$ ). Marine Geology, 131, pp. 47-56.

Martinson, D.G., Pisias, N.G., Hays, J.D., Imbrie, J., MoOre, T.C., \& SHACKLETON, N.J. 1987. Age dating and the orbital theory of the ice ages: development of a high-resolution 0 to 300,000 year chronostratigraphy. Quaternary Research, 27, pp. 1-29.

Maslin, M., Shackleton, N.J., \& PflaumanN, U. 1995. Surface water temperature, salinity and density changes in the northeast Atlantic during the last 45000 years: Heinrich events, deep water formation and climatic rebounds. Paleoceanography, 10, pp. 527-544.

Meese, D.A., Alley, R.B., Gow, A.J., Grootes, P.M., Mayewski, P.A., RAM, M., TAYLOR, K.C., WADDINGTON, E.D., \& ZIELINSKI, G.A. 1994. Preliminary depth-age scale of the GISP2 ice core. Cold Regions Research and Engineering Laboratory Special Report 94-1, Hanover, 66 p.

Nadeau, M.-J., Schleicher, M., Grootes, P.M., ERlenkeuser, H., Gottdang, A., Mous, D.J.W., Sarnthein, M., \& Willkomm, H. 1997. The Leibniz-Labor AMS facility at the ChristianAlbrechts-University, Kiel, Germany. Nuclear Instrumental Methods and Physical Research, B123, pp. 22-30.

PARK, M.-H. 1994. The marine environment in the eastern North Atlantic Ocean during the late Quaternary to present: mineralogy and stable isotopes. Masters Thesis, University of Kiel, 122 p.
Ruddiman, W.F. 1977. Late Quaternary deposition of ice-rafted sand in the subpolar North Atlantic (lat $40^{\circ}$ to $63^{\circ} \mathrm{N}$ ). Geological Society of America Bulletin, 88, pp. 1813-1827.

Sarnthein, M., Winn, K., Jung, S., Duplessy, J.-C., Labeyrie, L., Erlenkeuser, H., \& Ganssen, G. 1994. Changes in east Atlantic deepwater circulation over the last 30,000 years: eight time slice reconstructions. Paleoceanography, 9, pp. 209-267.

SCHÖNFELD, J., \& ZAHN, R. 2000. Late glacial to Holocene history of the Mediterranean outflow. Evidence from benthic foraminiferal assemblages and stable isotopes at the Portuguese margin. Palaeogeography Palaeoclimatology Palaeoecology, 159, pp. 85-111.

Stuiver, M., \& Pearson, G.W. 1993. High-precision bidecadal calibration of the radiocarbon time scale, AD 1950-500 BC and 2500-6000 BC. Radiocarbon, 35, pp. 1-23.

Stuiver, M., Reimer, P.J., Bard, E., Beck, J.W., Burr, G.S., Hughen, K.A., Kromer, B., MCCORMaC, F.G., vaN DER PliCht, J., \& SPURK, M. 1998. INTCAL 98 radiocarbon age calibration, 24,000-0 cal BP. Radiocarbon, 40, pp. 1041-1083.

Thomson, J., Nixon, S., Summerhayes, P., ROHling, E.J., SCHÖnfEld, J., ZAHN, R., GroOtes, P., Abrantes, F., GasPar, L., \& VAQEIRO, S. 2000. Enhanced productivity on the Iberian margin during glacial/interglacial transitions revealed by barium and diatoms. Journal of Geological Society of London, 157, pp. 667-677.

ZAHN, R. 1986. Spätquartäre Entwicklung von Küstenauftrieb und Tiefenwasserzirkulation im Nordost-Atlantik. Rekonstruktion anhand stabiler Isotope kalkschaliger Foraminiferen. Ph.D. Thesis, University of Kiel, $111 \mathrm{p}$.

ZAHN, R., SCHÖNFELD, J., KUDRASS, H.-R., PARK, M.-H., ERlenkeuser, H., \& Grootes, P. 1997. Thermohaline instability in the North Atlantic during meltwater events: stable isotope and ice-rafted detritus records from core SO75-26KL, Portuguese margin. Paleoceanography, 12, pp. 696-710.

Editorial responsibility: Robert A. Fensome 